\title{
Electrocardiogram External File Name
}

National Cancer Institute

\section{Source}

National Cancer Institute. Electrocardiogram External File Name. NCI Thesaurus. Code C83274.

The literal identifier of an external file name. 